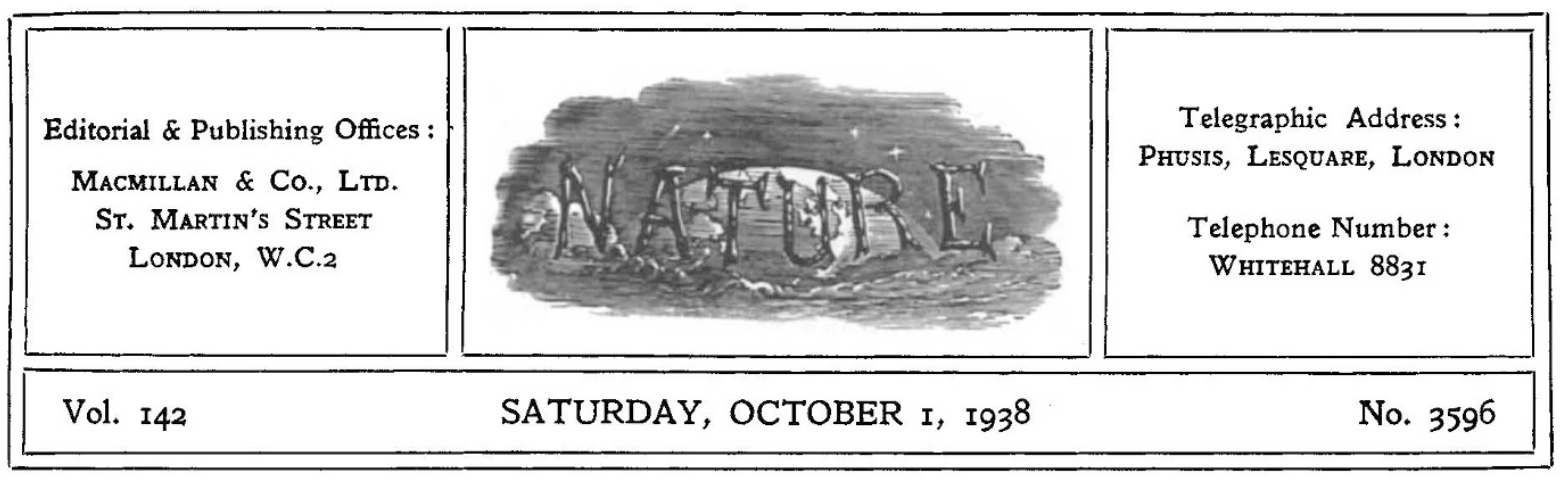

\title{
The Changing Outlook for Engineering Science
}

W

HAT policy should govern the content of university training in engineering science? What policy should govern research? What policy should govern relations with the community? These were the three main questions dealt with by Prof. R. V. Southwell in his presidential address delivered at Cambridge to Section $G$ (Engineering) of the British Association. No one, we believe, would disagree with Prof. Southwell that the time for a general stocktaking, such as is implied by the questions, has arrived.

"It is a commonplace," he said, "that the boundaries of natural science have so extended that no man can hope to comprehend the whole of physics or chemistry or any other field. But engineering science embraces all these fields; its boundaries extend not only continuously, as knowledge grows in tracts already surveyed, but at times by a sudden accretion of new territory-as when recently the new technology of plastics came to replace, for many purposes, older methods of fabrication in wood and metal. . . . What is to be our policy in the face of this continuous accretion of knowledge, seeing there is no corresponding increase in the capacity of undergraduates to absorb ?"

It will be generally agreed that mere lengthening or intensification of academic courses will not solve the problem, and that the planning of timetables, in Prof. Southwell's words, "must be conditioned first and foremost by ineluctable limits to the instruction we can give with confidence that it will really be assimilated"'. No intensification or lengthening of courses can guarantee the production of men of personality, educated to take wide views, which Prof. Southwell tells us are what industrialists demand. The filling of every hour of the working day by lecture or laboratory courses, which leave little or no time for "undergraduate activities", may well cut out just that part of a university training most likely to develop the very qualities that should be produced.

Clearly, in shaping courses, the purpose which they are to serve must be decided, and here Prof. Southwell's view is clear: "their purpose is to train recruits for industry, and the taking of honours in a final examination should indicate an assimilation of engineering principles adequate in a man who is starting a professional or industrial careerbut not more than this". With that end in mind he sees that "the real and difficult duty of a professor is to decide, not what subjects of instruction should be included because of value, but what can be omitted on the ground that, pushed into a mind already taxed, it will push out something still more valuable".

But how decide what can be omitted? Prof. Southwell would call industrialists into council; and in this connexion he puts his finger on a vital spot. Very rightly, he insists that the time is past when a student's three years at the university and his two years' apprenticeship can be regarded as distinct phases in training. The five years should be an integrated whole devoted to a single objective. $\mathrm{He}$ would therefore, with the industrialists, work out a plan to secure the recruits which are wanted. $\mathrm{He}$ would not neglect the importance of leisure in the formation of personality, and he would ask that industrialists scrutinize syllabuses, so that they may say whether items can be omitted either as never likely to be applied in practice or as being easily and more appropriately learned in works. 
He displays a proper educational care. He would not engage to drop a subject simply because an industrialist has not found it useful-that may be an accident of particular interests-but he would examine suggestions and find out, perhaps, "much that has crept into our courses more by accident than design".

There will be general agreement with all this : but there are difficulties which must not be overlooked. Who are the industrialists to be called in ? Is there a body of industrialists who can be asked to do what is required? The idea has been used, of course, in certain technical colleges : but when the need is for the re-shaping of university syllabuses; something more is required of the details of how industrialists are to be secured who can and will help in this work.

With Prof. Southwell's views on research we are in entire agreement. He has given the answer to the pessimistic view that engineering research at universities is doomed because, as it makes even fuller use of mathematics and physics and chemistry, its problems will be such as must more and more be referred to specialists in those subjects, and because of the vastly increased provision for ad hoc experimentation which has been made since the Great War in Government departments and in industrial concerns. As he points out, the engineer's problems are inexorable and he must so recognize them. The physicist, for example, is free to choose his "shapes" : they "are not dictated by constructional or manufacturing requirements, nor his materials by considerations of strength and cost". There are still countless problems of engineering, too difficult for routine investigation, which will provide vast scope for academic engineers.

When Prof. Southwell comes to the question of engineering as it concerns the life of the community, he reminds us that, because man has not learned to use his mastery of Nature wisely, he now often questions its value. "Because engineering includes guns, battleships, aeroplanes, tanks, therefore engineers are regarded as a class more than others responsible for the horrors of modern war." So runs the argument (with variations, of course; sometimes it is the chemist or some other specialist, but practically always it is "the scientist") we hear so often in these days of international trouble and crises. Prof. Southwell answers that the engineer is as much responsible as any man, but no more. We ought to be grateful for his succinct summing up of the matter when he says: "When men talk of 'beneficent' and 'destructive' science as though we were free to pick and choose, then I say they have not even begun to understand what science is." Obviously, we cannot have the benefits of science without its risks and temptations.

When the impact of science on life produces grave problems, hard and clear thinking is required; but here Prof. Southwell's view is that "we only confuse the issue when we intervene as specialists in discussions which concern us really not as specialists, but as members of a community". He thinks, therefore, that the scientific worker must come to political discussions unlabelled, in hours of leisure rather than give support to a notion that political problems will yield to something known as "the scientific attack". "Talk to me of the scientific approach in physics and I shall have some idea what you mean . . . talk to me of a 'scientific approach' to problems of real life, I shall suspect you of indulgence in mere jargon." He goes on to say that, instead of defending himself against the charges of dreadful responsibility for horrors, the man of science should devote himself to instilling into the public mind a clearer notion of the aims with which real scientific work is done. The popular notion of the "wonders of science" performed by workers aloof and remote from the world might be cleared up by giving a picture of these people doing their jobs and "seeking truth like artists because they must" - a picture not of the treasure found, but of the quest in search of it.

Such popular misconceptions must certainly be cleared up; but that is not enough. It may be argued that the search for abstract truth is not sufficient. Truth is relative, and the search for it must have some relation to the life of the community. For that reason a "scientific approach to problems of real life" cannot be regarded as mere jargon: and while it is not necessary to believe that a specialist in a particular subject will necessarily think clearly on matters of ethics and politics, nevertheless a scientific approach to modern problems can be formulated with enormous benefit to the modern world.

Prof. Southwell is to be congratulated on his stocktaking - the more so because he urges the obvious need for planning as the outlook for engineering science changes, and because, if that planning is to be done efficiently, we must strive to find agreement on problems which will not lightly tax both courage and skill. 